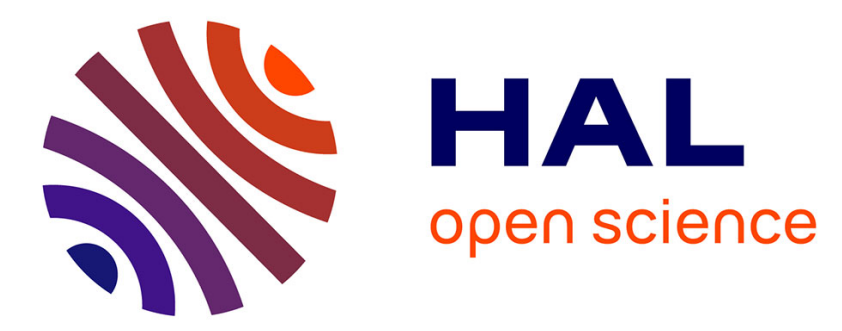

\title{
Hydrothermal Preparation of Manganese Zinc Ferrites
}

\author{
R. Lucke, E. Schlegel, R. Strienitz
}

\section{To cite this version:}

R. Lucke, E. Schlegel, R. Strienitz. Hydrothermal Preparation of Manganese Zinc Ferrites. Journal de Physique IV Proceedings, 1997, 07 (C1), pp.C1-63-C1-64. 10.1051/jp4:1997112 . jpa-00254760

\section{HAL Id: jpa-00254760 https://hal.science/jpa-00254760}

Submitted on 1 Jan 1997

HAL is a multi-disciplinary open access archive for the deposit and dissemination of scientific research documents, whether they are published or not. The documents may come from teaching and research institutions in France or abroad, or from public or private research centers.
L'archive ouverte pluridisciplinaire HAL, est destinée au dépôt et à la diffusion de documents scientifiques de niveau recherche, publiés ou non, émanant des établissements d'enseignement et de recherche français ou étrangers, des laboratoires publics ou privés. 


\title{
Hydrothermal Preparation of Manganese Zinc Ferrites
}

\author{
R. Lucke, E. Schlegel* and R. Strienitz* \\ Siemens Matsushita Components, Ferrites Division, Product Development, P.O. Box 8017 09, \\ 81617 München, Germany \\ * Technische Universität Bergakademie Freiberg, Institut für Silikattechnik, Agricolastr. 17, \\ 09596 Freiberg, Germany
}

\begin{abstract}
The hydrothermal powder preparation route is suited for achieving a very homogeneous, nanocrystalline franklinite powder. Compared to the conventional presintering via mixed oxide processing the hydrothermal route has advantages because of simplification for the powder preparation and more homogeneity caused by wet processes. As a result a preferritized powder suspension was synthesized which can be used to obtain a granulate and pressing it to the desired core shapes. The microstructure of the sintered cores is very homogeneous and almost free of pores compared to the conventionally produced cores. Excellent magnetic properties can be achieved by sintering under considerably lower temperatures. The initial permeability resulting from sintering under the same conditions is for hydrothermal based cores app. $20 \%$ higher.
\end{abstract}

\section{HYDROTHERMAL POWDER PREPARATION}

For the efficient large scale production of $\mathrm{Mn}-\mathrm{Zn}$-ferrite under application of commercial raw materials a presintering process is used in order to control the shrinkage behaviour and the residual-chlorine content. During this process ferritic substances are synthesized, mainly franklinite $(\mathrm{Mn}, \mathrm{Zn}) \mathrm{Fe}_{2} \mathrm{O}_{4}$, and lower contents of $\mathrm{Fe}_{2} \mathrm{O}_{3}$ and $\mathrm{Mn}_{3} \mathrm{O}_{4}$ are present.

If the reaction between the original oxides takes place in a water suspension, a considerably higher homogeneity can be achieved. The solubility of the oxides used for the ferrite production is low compared to the substances used in other works [1, 2]. But it strongly increases with growing water temperature. If the increased temperature in combination with water is the basis of the processability the product is hydrothermally derived.

The commercial ferrite production requires the application of available raw materials. In case of $\mathrm{Mn}$ - $\mathrm{Zn}$-ferrite these are iron oxides derived from the etching process. It consists of pure hematite and contains considerable amounts of chlorine which causes a weak acid reaction of the water suspension (pH app. 6). In contrary to the presintering process the chlorine cannot be removed during the hydrothermal process. This seriously affects the composition of the synthesised ferrite powder and leads to a zinc rich franklinite.

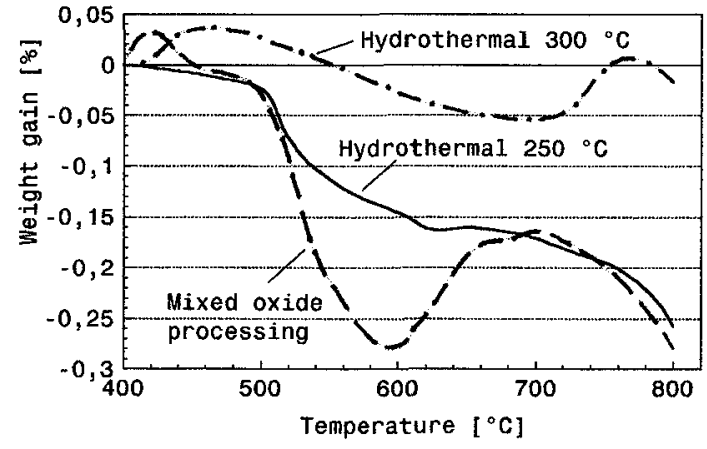

(a)

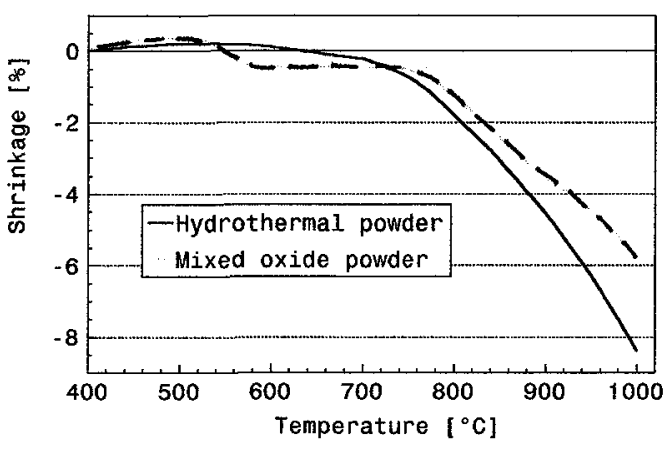

(b)

Figure 1: TGA (a) and shrinkage behaviour (b) of hydrothermal and mixed oxide powders 
The higher the temperature the more manganese oxide can react to ferrite. That behaviour is strongly dependent on the valency of the manganese oxide. $\mathrm{Mn}_{3} \mathrm{O}_{4}$ has a better hydrothermal reactivity then $\mathrm{MnO}_{2}$. In case of $\mathrm{Mn}_{3} \mathrm{O}_{4}$ a commercial material was used. The content of residual $\mathrm{Mn}_{x} \mathrm{O}_{y}$ after the hydrothermal treatment influences the reoxidation behaviour as well as the shrinkage behaviour of the pressed powder in the temperature range of $400-800^{\circ} \mathrm{C}$ (Fig. 1 ).

There is no hydrothermal reaction under conditions below $150^{\circ} \mathrm{C}$ detectable. Only at higher temperatures franklinite is obtained and in dependence of the hydrothermal conditions (temperature, reaction time) residual oxide amounts. There were no hydroxides analysed which is important for the subsecuent processing.

The franklinite crystals have a grain size distribution between 20 and $200 \mathrm{~nm}$. The appearance of the crystals is formed with respect to the cubic crystal system.

The density of subsequently sintered cores is proportional to the content of franklinite obtained by hydrothermal processing. The content of franklinite and oxides were measured using a X-ray powder diffraction system (Model Philips-X'Pert, $\mathrm{Cu}-\mathrm{K} \alpha$ radiation).

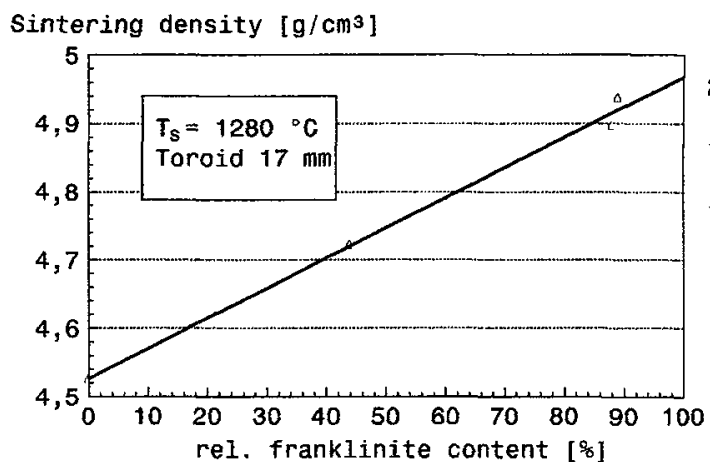

Figure 2: Dependence of sintering density on franklinite content $\left(\right.$ rel. franklinite content $\left.=\frac{\text { measured. franklinite }}{\text { franklinite.obtained. hydroth } . \text { at } .300^{\circ} \mathrm{C}}\right)$

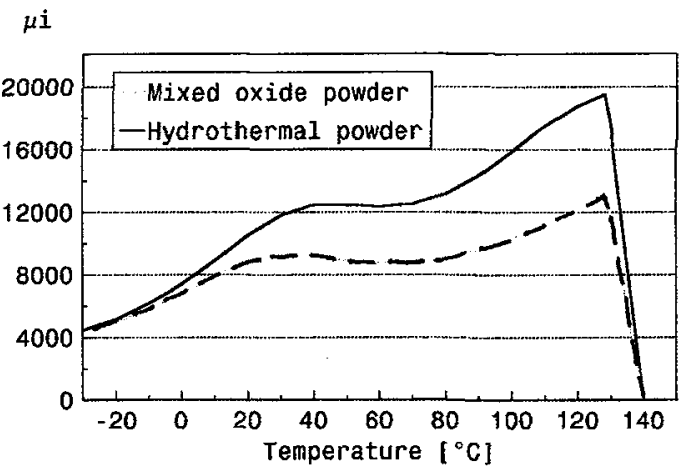

Figure 3: Temperature dependent permeability of toroids $(\varnothing=10 \mathrm{~mm})$ made of hydrothermal and mixed oxide powder $\left(1310^{\circ} \mathrm{C}\right)$

\section{MAGNETIC PROPERTIES}

The magnetic properties of toroids prepared of the hydrothermal powder are strongly dependent on a homogeneous densification of the powder. The handling and densification behaviour of nanosized powders completely differs from conventional ferrite powders. Following differences have to be taken into account for a production oriented processing:

- The nanosized powder tends to agglomerate; there has to be a dispersion equipment for the slurry

- The binder adsorption should be considered due to the higher specific surface area

- The drying of the slurry has to be carried out carefully because of the tendency of subsequent hard agglomerates which hardly can be destroyed by application of usual compacting pressures

The nanosized hydrothermal powder has a higher shrinkage at the same temperature compared to powder from the conventional preparation (Fig. 1). Moreover the microstructure shows a coarser grain size distribution $\left(d_{50}=10 \mu \mathrm{m}\right.$ versus $8.7 \mu \mathrm{m}$ for conventional preparation). This is an interesting feature to obtain higher permeabilities. The differences in the microstructure become visible in the magnetic properties (Fig. 3). There is a $20 \%$ higher initial permeability for the hydrothermal based toroids.

The sintering conditions have a very important influence on the magnetic properties. In case of hydrothermal powder the sintering temperature can be lowered and the conditions during the cooling down stage have to be adjusted.

From the technological point of view the hydrothermal powder preparation provides an interesting way for improved homogeneity and better product quality.

\section{References}

[1] Komarneni, S.; Fregeau, E.; Breval, E. and R. Roy, J. Am. Cer. Soc., 71 (1988) [1] C-26 - C-28

[2] Rozman, M. and M. Drofenik, J. Am. Cer. Soc., 78 (1995) [9] $2449-2455$ 